\title{
Features Of The Story Genre In "History Of The Four Nations"
}

\author{
Abdullaeva Marguba Dusmiratovna \\ Tashkent State University of Uzbek Language and Literature Candidate of Philological Sciences, Associate Professor \\ marg'ubaabdullayeva507@gmail.com
}

\begin{abstract}
This article is a scientific study of the literary features of the story genre. The stories in «The History of Four Nations» are analyzed from the point of view of the genre. Historical prose shows the role and significance of the genre of the story. The realistic essence of the stories, the variety of topics and educational aspects are revealed on the basis of the stories "Kobylai Khan", "Naked Father", "Oktaikhan", "Sultan Jaloliddin". The compositional structure of these stories, features of the plot system are revealed.
\end{abstract}

Keywords:

story, genre, literary sketch, "History of four nations", historical prose, composition, plot, originality, analysis.

Article Received: 18 October 2020, Revised: 3 November 2020, Accepted: 24 December 2020

\section{INTRODUCTION}

R.Jumaev in his research $[8 ; 11,12]$. Focusing on the "peculiarities of the storytelling tradition," he emphasizes that the storytelling genre is a unique literary phenomenon in Muslim Eastern literature. The story genre is based on event. Stories usually come within a particular piece. Therefore, the term "story" should not be considered the same as the term "story" in the modern sense. The story is an independent literary genre, ie: "a small epic genre in fiction, a work of prose in which the events of life are concisely expressed" [12; 330] means. However, stories have a significant role and influence in its emergence. In other words, storytelling is a genre that emerges as a result of the development of the story. Because in the story, as in the story, a relatively small reality is taken as the object of the image and description. The genre of storytelling is widely studied in literature. However, there is not much research on the narrative features of Persian and Turkish literature.

"One of the important issues is to determine the place of the Eastern storytelling tradition in the emergence of realistic stories. This requires some research. In particular, in what signs do the distinctive features that distinguish story and narrative as a literary genre, as well as bring them closer together and nourish each other, appear? ... Although the form of the story is small, the universe is able to contain and express the content. In this sense, formal brevity, brevity, conciseness and integrity are the traditional features of the story."

In this regard, it is important to study the roots and sources of the story genre, which is connected to the millennial history of our literature. Literary critic N.P. Utexin defines the leading features of the story genre as follows. According to him, the story shows human life from one perspective.

NP Utekhin's book, Epic Prose Genres, emphasizes that a characteristic feature of epic genres is event. Rabguzi's Qisasi Rabguzi also tells stories about prophets, judges, and doctors. These stories are instructive in nature and reflect the didactic features of the work. At the same time, Rabguzi made effective use of stories in folklore.

In terms of the number of stories in Persian and Turkish poetry, no work can be compared to Jalaliddin Rumi's epic "Masnaviyi ma'naviy". It can be symbolically called a "treasure trove of stories." In fact, the word "story" is used in the first line of the great epic:

Listen to the story, Complaints of separation. [9; 12] 
Therefore, in "Masnaviyi ma'naviy" the stories are included in the series of stories both separately and independently.

The famous Russian scientist V. M. While Zhirmunsky classifies international literary communication and interaction into four types, the fourth type is called "poetic novelism in the domestic context" and refers to the "stories" of the East.

also belongs to this type.

E.E.Bertels . He acknowledged that the story was "extremely interesting" but could not identify its source. E.E. Bertels made no mistake in emphasizing the similarity of his first story in "Masnaviyi ma'naviy" - "The King and the Maid", as well as the originality of the interpretation.

From the above, it can be seen that the story genre has been scientifically studied on the example of artistic and didactic works. However, the problem we raise is that the specific features of this genre in literary and historical works, its place in historical prose have not been studied and researched. From this point on, in historical and prose sources, we have tried to determine the characteristics of the story genre and its place in the historiography of that period.

In historical works, stories have a social, political, spiritual and moral content. In fiction, the narrative genre consists mainly of characters who can serve as role models in moral matters historical figures, kings, ministers, emirs, sheikhs, and wise, business-minded, enterprising people of the common people. Stories of the same type are cited in historical works in order to show events related to historical figures, to show their personal qualities, human qualities, nobility and other aspects. Stories of this content served to increase the enlightenment value of the work.

The composition of stories varies in works on historical themes. It does not have a stable construction. However, the plot of the story and a few images in it reflect the requirements of the genre.

"Jome' ut-tavorix" tells many stories about the life and work of the sons of Genghis Khan. For example, a story dedicated to Ugadaykhan. These stories provide information about the personal qualities of historical figures, their deeds, important human and moral qualities.

The stories told in historical and prose works have a didactic character. In the story about Ugadaykhan, the author collects oral works from various historical sources and describes them in an artistic way, showing that he has a beautiful morality and noble qualities. In addition, by the time Rashid al-Din wrote Jome' ut-Tawrih (1310/11 AD), Ugaday Khan had already passed away (in 1241). Rashididdin was a holistic and objective history of Genghis Khan's descendants, a collection of oral and written stories about them, a reliable history and objective literature. He achieved his goal. " .

Other stories in the play express the relationship between father and child, the issues of alliance between brothers, the attitude to the rules of Turkish statehood in an artistic and aesthetic way. In particular, the story of Ugadaykhan and Chigataykhan is noteworthy. The sincere and just resolution of the relationship between the brothers shows that the spirituality of the rulers is high, that the feelings of kindness are glorified. Ugaday says that Haqqan forgave Chigatay's sins and gave him the title of "Tikshimishi" given to highranking officials.

Jome'ut-tavorix was written in Persian. This work tells the history of the Turkic-Mongol peoples in an objective and scientific prose. The language of the work is simple and fluent, but also created in a unique figurative language. Rashididdin's Jome' ut-tavorix served as the primary source for historical works created in later periods.

We have also examined the events described as stories in historical works in the analysis of the story genre. In the History of the Four Nations, the story of the use of salt in the dhikr of Tung ibn Turk ibn Yafas is brief. "It is narrated that one day in a hunting ground, Tung ibn Turk ibn Yafas fell from the hands of a hot kebab. That place was a salt mine. In a salty place, salt is added to the hot kebab. Tung gave a different flavor when he put 
the bite in his mouth. Now he had cooked the whole kebab in that salt. He made his brothers and father, the arch state, and everyone aware of this pleasure. After that, they added enough salt to all the food.".

The story of Kublai Khan narrated in the play is also noteworthy. Kubilaykhan was extremely brave and energetic. His voice was so loud that the sound of his roar could be heard from seven corners. At that time, people called it Kubilay alp. It broke a man's spine just as a bow breaks an arrow. On winter nights, he would sleep next to huge trees, burning them high. Goho kept himself humble and laid a stone like a pillow while he slept. His whole body was full of strength and courage. In the battle with Altynkhan, he alone attacked Altynkhan's goal and sliced his chicken and telpa. His courage, bravery, and bravery were well-known and popular among the Mongols.

In the course of detailing the events related to Genghis Khan, another story about the "Naked Father" was told. The content of this story is about the man who conveyed the message that Temuchin was nicknamed Genghis Khan. "It is said that at that time there was a man in those districts, one of the bastards of the century, whom the Mongols called the God of Medicine. The Uzbek people called him Naked Father. Every word that came out of his mouth would have happened right away. It is said of him that he wandered barefoot in the mountain gorges and never shied away from the cold and heat. He would not communicate with anyone. He spoke in different dialects. Every word that was understandable to the people would come true immediately. He was both crying and laughing at the same moment. Suddenly, the Prophet (peace and blessings of Allaah be upon him) approached the crowd as he roared and cried and entered the game. yesterday informed me that we would hand over the soldier of the ruyi land to Temuchin and his children and hashish. We make many azimush-shan kings his trampling and tyranny. We will make all the great queens and great sultans mute and dependent on him. Now we will call him Genghis Khan. From now on, you will not call yourself Temujin, but you will protect the oppressed from the oppressors. ".

This is followed by a poem expressing the content of the story.

The story of Amir Kongir also glorifies his politeness and eloquence. It is said that Amir Kongir came to Genghis Khan's attention with these qualities.

In the course of detailing the events related to Genghis Khan, another story about the "Naked Father" was told. The content of this story is about the man who conveyed the message that Temuchin was nicknamed Genghis Khan. "It is said that at that time there was a man in those districts, one of the bastards of the century, whom the Mongols called the God of Medicine. The Uzbek people called him Naked Father. Every word that came out of his mouth would have happened right away. It is said of him that he wandered barefoot in the mountain gorges and never shied away from the cold and heat. He would not communicate with anyone. He spoke in different dialects. Every word that was understandable to the people would come true immediately. He was both crying and laughing at the same moment. Suddenly, the Prophet (peace and blessings of Allaah be upon him) approached the crowd as he roared and cried and entered the game. yesterday informed me that we would hand over the soldier of the ruyi land to Temuchin and his children and hashish. We make many azimush-shan kings his trampling and tyranny. We will make all the great queens and great sultans mute and dependent on him. Now we will call him Genghis Khan. From now on, you will not call yourself Temujin, but you will protect the oppressed from the oppressors." .

This is followed by a poem expressing the content of the story.

The story of Amir Kongir also glorifies his politeness and eloquence. It is said that Amir Kongir came to Genghis Khan's attention with these qualities. [See 10; 109]. 
The story given in the work "Dhikr of the children of the great wife of the great Genghis Khan" can be conditionally called "Genghis Khan's exhortation". This story not only enhances the educational value of the work, but also encourages the reader to take a positive approach to historical figures.

The story of Genghis Khan's will also contains interesting information. "The body of Genghis Khan was brought under a tree, and one day he fell under it under a hunt and said, 'This area is suitable for my mausoleum. put it down." His children and relatives obeyed the order. The steel coffin was baked on six sides in a ring. The coffin remained in the dome without a muallim. And they were afraid. The dome is now surrounded by forest. "The author also refers to the information he heard in his time. He connects the previously told story with his own time. It is clear from the story that this may have been from the author's oral narrations. "It is said that at the present time there is a corridor to the dome and several infidels have settled there. A satanic sorcerer enters the coffin and utters some words aloud. People hear this voice and look for meaning. The disbelievers who have built there try hard to carry out these satanic provocations by extracting the commandments of good and evil from those words and phrases to those who come to worship them. This dome is considered by those disbelievers as their Ka'bah. You can't go to the dome from that one narrow corridor, because it's covered with thick forest on all sides, and it's impossible to cross. ".

In the story of Oktaykhan, his kind advice urges us to act in solidarity, forgetting the angry quarrels between parents and siblings. "He said: The prince deserves generosity and purity. The work of the brave is not jealousy. Any round black thing can't be a piece. Whoever has a wise leader avoids hatred and envy. Do not listen to people who are greedy, follow the path of loving love. Otayu otabek and me, why are you rude to me? Kings will not be mad, and there will be no mercy for a stranger's child. Shahriyor's language does not know rest. Why do you care about the words of your enemies? Avoid these lofty words. Obey the decree of Hakan. A label came from the owner. It is your concern for us. Let's chase the conflict from the heart, let's rely on unity. Let's fight in unison, until both boys heard the label until they captured the castle. Father's cry made their hearts tremble. In the words of Oktay, they reduced the flames of this brother's heart. They removed the enmity from their breasts and made it as clear as glass." .

Such advice and instructive words from the language of Oktaykhan led them to victory. Chigataykhan, Jochikhan and Oktaykhan lined up and went to war.

We know that before the battle, the great commander and the ministers gave exemplary and exemplary speeches in a way that influenced them, awakened their spirits, reminded them of their duty, in order to raise the fighting spirit of the army. This, in turn, was a spiritual strength to the soldiers. He helped them fight valiantly in battle.

Another exemplary story is given in the dhikr of the reign of Oktaykan ibn Genghis Khan. For example, it says: I do not agree, because they are a sect that must kill the wicked people! "Some of the archons of the state believed his words, and thought that perhaps this word was true. His Majesty thought for a moment and said, "There is no truth in this statement, of course, it is a lie, and I cannot help but doubt it, because the great Genghis Khan did not know any language other than the great Mongolian language, and he does not know the Mongolian language at all. There is no doubt that this statement is a lie!" He immediately ordered the execution of that man. He had great respect for Muslims on the occasion of his state. Oktay Qaon, with his generosity, generosity and justice, was superior to all his other brothers, so he had appointed him to the throne before his father's death. It is said that the word Oktay means "ascending" in Mongolian.

The enlightening significance of this story is that Oktaykhan's assessment of the situation with deep thought and understanding is 
exemplary. This story, which promotes a thousand thoughts to one thought, a seven-dimensional cut, encourages rulers and princes to act thoughtfully and wisely. A story on the same subject is given in Shajarayi Turk and in the Dhikr of some of the deeds and deeds of Ogadoy Qaan.

A poetic story in the narrative of events related to Sultan Jalaliddin caught our attention. This story contains philosophical observations about the transience of the wealthy state. The content of the poetic story is as follows: "O judge, do not think that the main purpose of this epic is to describe the intensity of the battle. Perhaps think that because of a king like Khorezmshah, the world was completely sheltered. He was equal to heaven in greatness and power. His army was more than a star. Decrees were in effect in every country. There was no account of the army at every address. In short, nothing of those things remained. There is not a penny left in the world in his name. How many great ones and three happy sons they had, one after the other, as kings. Not one of their descendants was left, and not one of the innumerable treasures was left. The situation became clear (from this epic) that nothing in the world goes to nothing. Nothing lasts in the world except the pure Creator. Every king should be aware of this secret and not sit on the throne. ".

From the content of the story it is clear that the decline of the great Khorezmshah state, the tragic fate of the sultans should be taken as an example.

The throne is given in a philosophical observation about the transience of the world, that the wealth state is not eternal. In the epic of Sultan Jalaliddin, thanks to Khorezmshah, the people of the world are sheltered, his greatness and power are equal to the sky. It is praised that the army has no account, that every decree is in effect. But it is sadly described that none of this remains.

In short, it can be seen that the stories cited in literary-historical works are narrated on a variety of subjects. In the details of the marches, battles, and lives of kings, princes, and generals, the exemplary words, deeds, and actions of a wise man, king, or minister are briefly mentioned.
Therefore, the stories do not repeat each other in terms of form and content. So what is the purpose of stories in historical works? The analysis of this question can be concluded as follows:

to narrate the exemplary deeds of a historical figure;

in order to inspire the army before the battle; to instruct and exhort their children;

used to strengthen parent-child and sibling relationships.

\section{REFERENCE}

[1] Literary types and genres (On history and theory). Three volumes. Volume 1 Epos Tashkent: Fan1991-B 33.

[2] Bertels E.E. Sufism and Sufi literature M.1965 - p 405-406.

[3] Boltaboev H. Stories of "Masnavi Sharif". In the following book: Mawlana Jalaliddin Rumi. Masnaviyi spiritual. Notebooks 1, 2 and 3. Completed 3rd edition- Tashkent: "Sparks of Literature" Publishing House. 2014 - 418 p.

[4] Vladimirova N.V. Ideas and images in Uzbek stories. - T 1969.

[5] Mirzaahmedova M. Hoja's stories. Written dissertation for the degree of F.f.n. $-\mathrm{T}$ 1970.

[6] G'anixo'jaeva N. On the main sources of Navoi stories // Uzbek language and literature - Tashkent, 1967 - № 4,- Б. 2023;

[7] Jirmunskiy V.M. Comparative literature. L Nauka, 1979 - P.158-173

[8] Jumaev Rashid Normurodovich. Comparative analysis of Masnavi spiritual and stories in "Lison ut-tayr" .PhD diss-ya. Avtref. - T .2018 - B 11-12.

[9] Mawlana Jalaliddin Rumi. Masnaviyi spiritual. First, second and third notebooks. Translation from Persian by the People's Poet of Uzbekistan Jamal Kamal. Corrected third edition. - Tashkent: "Sparks of Literature" Publishing House. 2014 - Б. 12. 
[10] Mirzo Ulugbek. History of four nations. Tashkent: 1993. - 352 p.

[11] Rakhmonov N. History of Uzbek literature. - Tashkent: "Sano standart". 2017 - P 299.

[12] National Encyclopedia of Uzbekistan. Volume 11 - Tashkent: State Scientific Publishing House "National Encyclopedia of Uzbekistan" 2005 - 330 p. 